\title{
TESTING AN OPERATION OF PROTOTYPE FOR AUTOMATED ASSESSMENT: CASE OF VISITOR PROFILE OF GAUJA NATIONAL PARK
}

\author{
*Iluta Berzina, Edgars Balodis \\ Vidzeme University of Applied Sciences, Latvia \\ *Corresponding author's email: iluta.berzina@va.lv
}

\begin{abstract}
This study is based on the authors' research started in 2017 that resulted in the development of theoretical strategic and tactical models for the construction of a prototype for automated assessment of tourism economic impact in specific regions, including regions of national parks (NP), as well as for other studies. The aim of the research was testing the performance of the prototype in a research e-environment using the travellers' survey data obtained in a study in 2019 on the national parks' target groups (visitor behaviour) during the Gauja National Park (GNP) Travellers' Days. The prototype was based on the open-source platform Drupal, MySQL used as a database management system (DMS). Drupal united with the Jupyter Notebook platform. The methodological substantiation of the test study is based on aspects of consumer behaviour. A quantitative study with details of qualitative research has been performed. Simple data sampling was used in the data acquisition, but in the analysis - induction, deduction approach, synthesis, data sorting and segmentation, determination of mean values and their expression in proportion; a comparative analysis was performed and conclusions characterizing the sample were made. After completing the prototype performance testing, the authors' main findings indicate that the prototype's performance efficiency in terms of time consumption is 23.3 times higher than equivalent work in MS Excel. The prototype has yielded quantitative results from the calculations, and that allows the formulation of the GNP's Travellers' Days visitor profile, which is characterized by a sample of the surveys.
\end{abstract}

Key words: prototype, automatized assessment, visitor profile.

\section{Introduction}

Technologies are constantly evolving in the world, developing a digital era. The market intelligence company 'International Data Corporation' (IDC) believes that digitized information has the potential for a variety of applications that facilitate work in the e-environment. The IDC has named three primary locations where digitalization is happening and where digital content is created: (1) the core (traditional and cloud data centres), (2) the edge (enterprisehardened infrastructure like cell towers and branch oces), and (3) the endpoints (PCs, smart phones, and IoT devices). The summation of all this data, whether created, captured, or replicated, is called the Global Datasphere, and it is experiencing a tremendous growth. The IDC predicts that the size of the Global Datasphere will grow from 33 Zettabytes (ZB) in 2018 to $175 \mathrm{ZB}$ by 2025 . According to the IDC's 'Data Age $2025^{\prime}$ 'white paper, it means, if a person attempts to download 175 zettabytes at the average current internet connection speed, it would take 1.8 billion years to download. The real-time data represents $15 \%$ of the Global Datasphere and nearly $30 \%$ by 2025 (BWMC Ltd, 2020; Reinsel, Gantz, \& Rydning, 2018).

Much of today's economy relies on data, and this reliance will only increase in the future. Data is helping reach new markets, streamline operations, helps better recognize, serve and attract customers, and analyse several processes (Reinsel, Gantz, \& Rydning, 2018).

For example, in Latvia the territory of national parks (NP) is divided into functional zones according to conservation and utilization purposes. In some of these zones, natural resources are completely excluded from economic and other activities, or only economic activities that do not significantly change the structure of the historically formed landscape, including natural and cultural values, are allowed (Saeima of the Republic of Latvia, (the Parliament), 1993). It is therefore important to develop a sustainable tourism business and to elaborate a sustainable tourism product strategy in the NP territories. It is justified by the reasoning made in the data-based evaluation of the situation. This is why the Nature Conservation Agency of Latvia (LNCA) in collaboration with the Association 'Cesis District Rural Partnership' (CDRP) and the Northern Kurzeme Business Association (NKBA) conducted a study on national parks' target groups (visitor behaviour) in two NPs in the period 2018-2019 which was carried out by the Institute of Social, Economic and Humanities Research of Vidzeme University of Applied Sciences (ViA HESPI). The aim of the study was to obtain information to support the development of strategic documents for sustainable management and development of territories by exploring the behaviour - unknown facets of the Slitere NP (SNP) and Gauja NP (GNP) target groups (Association CDRP, 2019). According to the study objectives defined by the LNCA, the target group for the particular study was NP visitors. The required primary data was collected during 2018-2019 Traveller Days, incl. in the GNP 15-16 September 2018 and 14-15 September 2009. These events provide easier access to the target group, and hence the data, and the NP Traveller Days focus on both the most typical NP tourism offer and the most characteristic demand.

It is noteworthy that until 2018 there was only 
one NP Travellers' Days evaluation carried out - as a feedback from the target group of the first SNP Travellers' Day event in 2010. It was carried out by the Professional Rural Tourism Association 'Rural Traveller' (PRTA RT, 2010). The time-consuming and manual work-intensive MS Excel environment was used, in comparison with the performance of any database software.

However, the digital era reflects in science. The usual triad 'researcher-research tools-object of research' is changed and turns into a cyber-physical system - a new triad 'engineer-design tools-prototype/ product' interpreting scientific results by new research techniques or/and methodologies (Gero, Tsybulsky, \& Levin, 2019).

This study is based on the authors' research work started in 2017 that resulted in the development of theoretical strategic and tactical models for the construction of the prototype. It is based on a combination of open source platform capabilities in order to automate the process of assessing the economic impact of tourism in specific regions, including NP regions, as well as to perform other studies using the data stored in the 'Data Bank' section of the prototype. The prototype consists of two interconnected digital applications - 'Data Bank' and 'Data Analysis' - as a unified solution for research in the e-environment. At the present stage, it integrates the methodology developed in 2012 in Latvia University of Agriculture (now Latvia University of Life Sciences and Technologies) for assessing the economic significance and the impact of tourism in specific regional areas (Berzina, 2012), without the possibility of statistical analysis (statistical verification of results), as well as the theoretical possibility of using mobile positioning data (MPD) so that results can be expressed spatially (Berzina \& Lauberte, 2018; Berzina \& Lauberte, 2019).

Mobile data is the internet content delivered to mobile devices such as smartphones and tablets over a wireless cellular connection (TechTarget Ltd, 2020). In the world, MPD-based technologies are evolving just like MPD consumption. This is evidenced by the global study carried out by Swedish company Tefficient AB Ltd in 2019 which concludes that Europe is a world leader in mobile data consumption and growth. In 2018 in Europe, JSC Latvia Mobile Telephone (LMT) ranked 5th in the world by mobile data usage (GB) per month per unique user (SIM) (19.2 GB / SIM), Tele $2-8^{\text {th }}(10.3 \mathrm{~GB} / \mathrm{SIM})$, but Bite $\mathrm{LV}-13^{\text {th }}(7.6 \mathrm{~GB} / \mathrm{SIM})$, while Finland was the world leader (the company DNA - 23.5 GB / SIM), but Italy (103\%) showed the fastest growth (Tefficient AB Ltd, 2019). However, there is a prolonged stagnation in the practical availability of anonymised MPD in Latvia for research purposes. Mobile network operators (MNOs) do not provide data on the basis of Regulation (EU) $2016 / 679$ on the protection of natural persons with regard to the processing of personal data and on the free movement of such data which entered into force on 25 May 2018 (EP \& EC, 2016). Latvia is in the process of searching for a fundamental solution in the potential use of MPD. Namely, on 1 January 2019 the amendments to the Electronic Communications Law (2004, with amendments made until 16 January 2020) came into force in the Republic of Latvia (LR), which stipulate that the Central Statistical Bureau of Latvia (CSB) has the right to use the data at the disposal of MNOs for the provision of statistics (LR Saeima (the Parliament), 2004). However, there are no regulations of LR Cabinet of Ministers on how to ensure it. There are on-going discussions on the development of the regulations and the result is not expected soon. 'It is possible that MNOs are seeing not only an innovative approach here, but also a new business niche alongside the existing services. For example, LMT is based on the model that the company operates with its own data and can, by attracting researchers, prepare solutions for government or commercial organizations. Consequently, the question of who will do the research and how it will be done remains open in Latvia' (Jurkāns, 2019). Nevertheless, the ability of the prototype to work with MPD has been tested using synthesized MPD. The results obtained do not allow affirming, but allow suggesting that at least theoretically the prototype can recognize MPD. The MPD synthesis used a structure (anonymised CDR data including call and internet usage time, GPS coordinates, mobile device (not number) ID, SIM residency) that was included in the 2017 Liberia example - report 'Call Detail Record (CDR) Analysis: Republic of Liberia. Final Report. Republic of Liberia 2017' (ITU, 2017).

The aim of the research: testing the performance of the prototype in a research e-environment using the travellers' survey data obtained in the study conducted by ViA HESPI in 2019 on the national parks' target groups (visitor behaviour) during the Gauja National Park (GNP) Travellers' Days in order to determine the GNP visitor profile. Tasks of the research are as follows: (1) Test the technical operation of the prototype; (2) Describe the operation of the prototype; (3) Present the results of the test study regarding the visitor profile of the GNP Travellers' Days; (4) Draw conclusions.

\section{Materials and Methods}

The methodological substantiation of the test study is based on the aspects of consumer behaviour (action), which are evaluated in market research in social, economic, marketing, etc. areas, and are related to external and internal factors of an 
individual's purchasing or consumption decision: (1) Economic (income level, solvency); (2) Social (belonging to a particular social class, status in society, etc.); (3) Cultures (cultural level, educational level, nationality, religion); (4) Personal (age, life cycle stage, profession, lifestyle, character, etc.); (5) Psychological (motivation, perception, attitude, habits) (Association CDRP, 2019). There is no better way to objectively understand the current situation than to organize a survey - collect information from respondents in the locations (e.g., lodging properties, restaurants, attractions, retail shops, and outdoor recreation spots, etc.) they have visited while in a destination (University of Minnesota Extension, 2020). The methodology applied is a combination of a number of scientific techniques which was developed and scientifically approbated in 2011 when formulating the profile of the Kemeri NP (KNP) visitor profile. It is based on a combination of research techniques developed and tested in Australia, the USA and Finland, which is based on surveys (or interviews) as the data acquisition method. The questionnaires are quite complex and include: (1) Filter questions; (2) Structured answer questions (closed questions); (3) Multiple choice questions; (4) Dichotomous choice questions; (5) Unstructured answer questions (open questions); (6) Free-answer questions; (7) Response scale (Berzina \& Grizane, 2011). For the purpose of investigating the target group, the questions in the survey are organized so that the data can be segmented into 4 criteria groups. They consist of several sub-criteria: (1) Demography - gender, age, place of residence, education, occupation, work status, composition of the traveller group, income, travel expenses, willingness to pay; (2) Activities frequency of travel, destination of the trip, length of stay in the territory of the NP, place of stay, mode of travel, attendance of events; (3) Acquisition of information; (4) Attitudes - the motive of the trip, travel decision factors, the overall rating of the NP Travellers' Day and the assessment of the likelihood of recommending to others, alternative choices (Berzina \& Grizane, 2011). In this approach, the final score is the result of each assessment with the highest frequency ('majority wins') in the analysis after the data collection, thus yielding a higher arithmetic mean value, which is normalized in proportion to the sample set. The total sample of $n=268$ consists of the GNP Travellers' Day direct target group - NP visitors (Association CDRP, 2019). In order to determine the GNP visitor profile, quantitative research with details of qualitative research was performed in the prototype testing. For acquisition of primary data, simple random sampling was used, where the principle of equality is respected. The results, on the other hand, are the result of a partial statistical observation of a part of the general set - a sample, with the purpose of obtaining a general idea. Induction, deduction approach, synthesis, data sorting and segmentation, determination and expression in proportion, qualitative information quantification was used, comparative analysis was carried out, conclusions regarding the sample were made (Association CDRP, 2019).

The research used a part of the data set that could be obtained and processed even for the analysis of tourism EI - on the principles of this analysis the prototype design and technical development were based. For the sake of controlling the accuracy of the results, the study was carried out both in MS Excel and by using the prototype capabilities for automated acquisition of results, which is not related to the inclusion of MPD (Figure 1).

The model is based on the open source platform Drupal that ensures that there is no need to buy/ subscribe to licenses. MySQL is used as a database management system (DMS) for 'Data bank' of

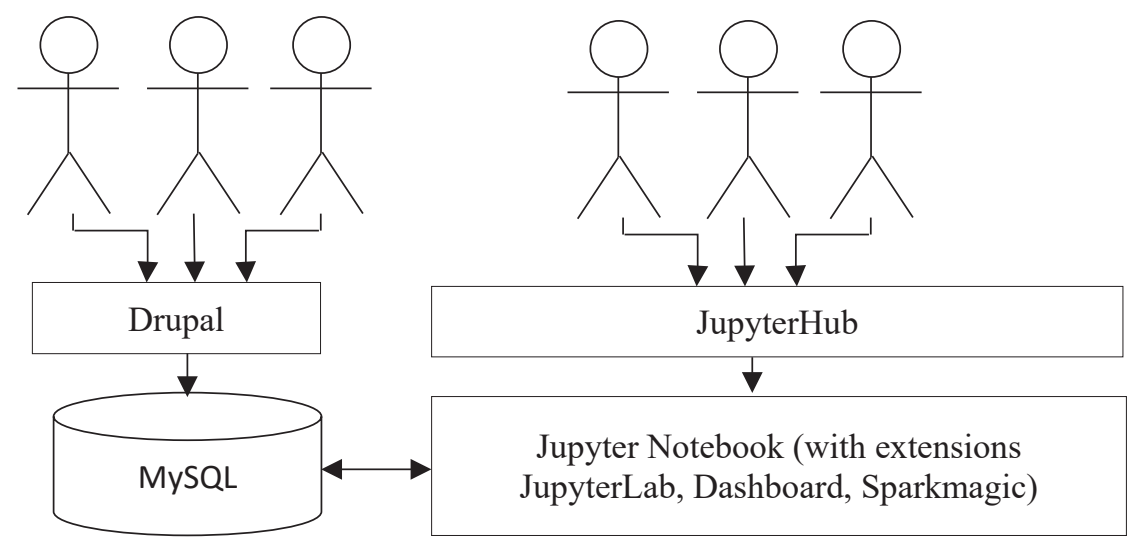

Figure 1. Tested part of the prototype - fragment of the tactical model for the construction of the prototype for automatized assessment of appropriate tourism issues

(Created by the authors, according to Berzina \& Lauberte, 2019). 
traditional data. Using the 'Data Bank' content management system (CMS), Drupal authorized users are able to create new multi-language survey forms, sort the data submitted there, and create new data views. The 'Data analysis' interactive interface allows an easy and fast data analysis. Drupal united with the Jupyter Notebook platform and extensions, and the code developed in the Python languages to get the power for actions by data, because Drupal has the ability to collect information, but Jupyter Notebook to process and analyse traditional data (Berzina \& Lauberte, 2019). In accordance with the prototype Software Design Description (SDD), the prototype includes the following users and their roles:

(1) System Administrator - as an authorized user with full system administration rights, he/she creates and/ or corrects any content, data fields, views; he/she creates new domain entries and their paths, administers users and their rights, translates the application interface, administers blocks and modules, site menus, default configuration and changes its appearance. He/ she views, deletes audit log entries;

(2) Content Administrator - as an authorized user who has the right to edit existing, create and publish new questionnaires, as well as translate their content, he/she views, edits all submissions of all questionnaires, views revisions of value changes entered by external data sources and restores/ deletes records. He/she administers existing content types, input fields, data views, administers the main menu bar, as well as the tool menu block;

(3) Public user (respondents) - fills in the questionnaire;

(4) Analyst - as an authorized user who has the right to edit existing, create and publish new questionnaires, as well as translate their content. He/ she views, edits all submissions of all questionnaires, enters data from external data sources, views their value change revisions, restores/ deletes entries.

\section{Results and Discussion}

The testing sequence according to the prototype user roles:

(1) System administrator, while performing all the functions of the role, played a continuous observer and consultant role in the testing as he is also the technical developer of the prototype. The main view of the prototype shows its structural units - menus, tabs, tools, question groups in the questionnaire. When testing the performance of the prototype, no negative features were observed in the performance of the system administrator and at the same time the technical developer of the prototype;

(2) Content Administrator - In the 'Data bank' section of the prototype, 1 questionnaire in Latvian was created and published, consisting of 26 questions, one of which was an unstructured or open question. The questionnaire consisted of 7 open-ended question answers and 5 answer scales. This is part of the administration of content (response) types, input fields, data views. When administering the main menu bar, the tool menu block was organized. According to the methodology used, the study did not require input of external (secondary) data or value change revision. Therefore, the 'External Data' block in the 'Database' part of the prototype developed by the system administrator was not used in the test study, although its performance was verified by the analyst using synthesized data - entering and then deleting them. In this way, both the particular block and the other entry sections were technically tested. The possibility of restoring or deleting entries was used to correct some inadvertent errors that occurred during the data entry. No negative features were observed in the performance of the prototype;

(3) Public User (Respondents) - during the testing of the prototype, the public user function was performed by the analyst by manually transferring the data from the questionnaires in printed format into electronically prepared questionnaires in the 'Data bank' section of the prototype. They were available on 4 mobile technical devices -2 tablets and 2 mobile smartphones - and 1 computer via a single Internet Protocol (IP) address created using WiFi over a wireless local area network. The prototype development phase does not provide for the creation and subscription of a domain that would allow data to be entered online, i.e. through one of the internet browsers. No negative features were observed in the performance of the prototype;

(4) Analyst - also given the role of the content administrator, but during the test study the analyst performed the data analysis of all the submissions in the questionnaire according to the methodology, i.e. segmentation of the data, summation, expression in proportion and visualization in bar graphs. The answers of the open-ended questions were segmented, the prototype divided them and created a list of answer variants also according to the segments. All the results can be exported in csv format and saved on a Drupal server for opening the file. Concurrently with the work in the prototype environment, the test study data entry and the calculations of the results were performed also in the MS Excel environment. The difference observed when comparing the results in the two environments used was in the final result, which showed up at the seventh digit after the decimal point - a change of one digit sometimes in the direction of value growth and sometimes in the direction of decline. Therefore, it can be generally considered that no negative features were observed in the performance of the prototype. 
According to the methodology, in the prototype component 'Data Analysis' the division of respondents into three segments was performed: (1) NP inhabitants, (2) one-day travellers and (3) tourists. It is the basis of the structure for characteristics and calculations included in the assessments. At this moment, the prototype is able to perform the functions of summation and comparison (difference determination), in specific cases - division, multiplication and expression of results in percentage (\%). The determined profile of the direct target group of the GNP Travellers' Days: A woman living in Latvia - a one-day traveller aged 16-45 with a university degree having a job in trade or finance sector. The monthly salary is up to $500-900$ EUR. She spends the weekend in the GNP Travellers' Days travelling with 3-4 family members, friends, relatives or acquaintances aged $18-65$. She repeatedly visits the GNP Travellers' Days though it is not the destination of her trip. She covers a distance of up to $100 \mathrm{~km}$, travelling by a private car and spending up to 1.5 hours during the trip. When attending the event, her expenses of up to $€ 20$ are mostly made up of transportation-related and catering services, and the woman would not like to see any further increase in costs. While attending the GNP Travellers' Days, she is confident that the GNP area is a clean, natural and safe environment, as well as expects valuable event programme content, and the area is easily accessible having the necessary infrastructure. It is of little importance to her that the GNP area is a Natura 2000 site. She plans to spend between three hours and one day on the GNP territory. The woman gets information about the destination and event from news on the web and from communication with friends, relatives, acquaintances or colleagues. As an alternative to visiting the GNP's Travellers' Days, the traveller would choose to stay home or visit relatives, friends, acquaintances or colleagues. The attended activities of the event are rated with 4-5 points, but she would wish for a variety of activities, better value for money and thinks that the provision and availability of information is a major issue to be improved by the event organizers.

From the technical point of view, these are not complicated procedures and at this point the right choice of the programming language was the database management system (DMS) MySQL for traditional data. It remains unknown whether the Diederich $T$. (2018) finding that MySQL is not suitable for large scale high-quality data analysis (Diederich, 2018) can be supported because the 'Data bank' part of the prototype does not contain a large array of data that can be generated over time, in larger and more frequent surveys, and also if the prototype had been developed so far that statistical verification of the obtained research results would be possible. During the test procedure, the authors obtained assurance that the prototype built on the Drupal platform worked fast, the CMS was easy to understand for users regardless of their role (except for the public user who did not need to understand it). The previous theoretic assumption was confirmed, namely, that Drupal is a lightweight platform made for fast performance and it has features for managing content types, which is useful for creating data views, and it has a good user permission management. The Drupal use is free of charge and does not require special permits and licenses (Berzina \& Lauberte, 2019). The survey data of research site visitors is stored in the MySQL database, just like the data analysis results in the data analysis section. Since Jupyter Notebook is an open-source web application that allows creating and sharing documents that contain live code, equations, visualizations and narrative text, it was used as a prototype technical development tool by the system administrator when creating the visualization code for the analysis of the results in Python programming language. In the test study, no negative features were observed in the visualization of the results, confirming that the use of the Jupyter Notebook in the prototype development was useful, allowing to obtain results that are also expressed in bar graphs.

If the functions of the prototype are evaluated in comparison to MS Excel, the authors have arrived at several conclusions and also agree with Natter, E. (2019) - MS Excel spreadsheets are frequently used tool for collecting and organizing data, which is among the simplest of its uses. Information can be placed in columns and rows, sorted by information type, analysed and put into charts or tables for viewing and interpretation. However, the downside is that only the information that the user chooses for analysis is included in these presentations, and therefore, other pertinent information that may influence decision making might be excluded. The difficult part for users is that the calculations must be entered into the spreadsheet as formulas. This requires learning the correct syntax for each type of calculation. However, many classes are available to learn the skills necessary to use these formulas. If the syntax is incorrect, the programme will not return the correct information when the calculations are run. Additionally, if users input wrong data, even in only one cell of the spreadsheet, all related calculations and cells will be affected and have incorrect data. In today's collaborative work environment, multiple users often need access to the same documents. If using MS Excel, the spreadsheets can be shared, but only one user can change data at a time. Fundamental deficiency - there is no file history. Another spreadsheet disadvantage is the lack of security for files. Some data collection software therefore may be a more suitable option 


\section{Processing time of questionnaire and data in MS Excel and prototype environments} (Created by the authors)

\begin{tabular}{|c|c|c|c|c|c|c|}
\hline $\begin{array}{l}\text { Sequence of actions per- } \\
\text { formed }\end{array}$ & \multicolumn{4}{|c|}{ Indicators/ criteria groups } & $\begin{array}{l}\text { MS Excel } \\
\text { (spent time } \\
\text { h:m:s) }\end{array}$ & $\begin{array}{l}\text { Prototype } \\
\text { (spent time } \\
\text { h:m:s) }\end{array}$ \\
\hline \multicolumn{7}{|c|}{ 'Data bank' } \\
\hline \multicolumn{5}{|l|}{ Preparation of questionnaire } & 01:06:00 & 00:49:00 \\
\hline \multicolumn{5}{|l|}{ Data entry } & 00:05:00* & $00: 01: 00^{* *}$ \\
\hline \multicolumn{7}{|c|}{ 'Data analysis' } \\
\hline \multirow[b]{2}{*}{ Selection of data } & Demography & Activities & $\begin{array}{c}\text { Information } \\
\text { sources }\end{array}$ & Attitude & & \\
\hline & 00:03:30 & 00:03:30 & 00:02:00 & 00:03:30 & $00: 12: 30$ & 00:03:00 \\
\hline Summing of data & 00:01:00 & 00:01:00 & 00:01:00 & 00:01:00 & 00:04:00 & 00:00:06 \\
\hline $\begin{array}{l}\text { Results expression in pro- } \\
\text { portions (\%) }\end{array}$ & 00:04:30 & 00:04:30 & 00:01:00 & 00:04:30 & $00: 14: 30$ & 00:00:05 \\
\hline $\begin{array}{l}\text { Selection and preparation } \\
\text { (sorting) of results for } \\
\text { visualisation }\end{array}$ & 00:06:00 & 00:06:00 & 00:03:00 & 00:06:00 & 00:21:00 & 00:00:04 \\
\hline $\begin{array}{l}\text { Visualization of results } \\
\text { (graphic presentation) }\end{array}$ & 00:08:00 & 00:08:00 & 00:05:30 & 00:08:00 & $00: 29: 30$ & 00:00:12 \\
\hline & & & & Total: & $01: 20: 30$ & $00: 03: 27$ \\
\hline
\end{tabular}

* Data entry on one device (1 questionnaire)

** Data entry from five devices simultaneously (5 questionnaires)

(Natter, 2019). The mentioned shortcomings of MS Excel are not observed in the prototype environment and work on it requires significantly less time. The authors present an example of processing the data of five questionnaires (Table 1).

Despite the fact that the time consumed depends on both the size and complexity of the questionnaire and human factors such as the speed of work, it has been concluded in the result summary that working in the prototype environment is more efficient in terms of time spent both for questionnaire design, data entry and analysis processes. In total, the work in the prototype environment with the questionnaire and the data starting from input to result using 5 questionnaires from 3 different respondent segments as well as 5 devices consumed 23.3 times less time than the same workload in MS Excel environment. Therefore, the use of the prototype in data input, selection, filtering, transformation in order to perform data preparation for analysis and also the analysis and visualization of results can be considered more efficient than the use of MS Excel. One of the reasons - MS Excel is not suitable for multi-user mode, unlike the prototype capabilities - data entry can occur simultaneously from an unlimited number of devices and data consolidation is done immediately because it is automatic. In addition, MS Excel is only integrated with MS infrastructure, which are often paid products, besides that, the user should have a good knowledge of MS Excel. There are no such restrictions in the use of the prototype, although the results can be opened and saved in csv format, as provided also by MS Excel.

\section{Conclusions}

1. The performance of the prototype, corresponding to its stage of technical development, has been tested and demonstrates that:

1.1. Drupal is fast-performance and it has features for managing content types, which is useful for creating data views, and it has a good user permission management;

1.2. From the technical point of view, it was the right choice of the programming language selection where the database management system (DMS) MySQL for traditional data was used. It remains unknown whether Diederich T. (2018) finding that MySQL is not suitable for a large scale high-quality data analysis can be supported;

1.3. The use of Jupyter Hub and Jupyter Notebook with extensions in the development of the prototype has been useful;

1.4. Users' roles did not cause any problems in the prototype testing. This allows assuming that they are organized in an appropriate hierarchy and proportions; 
1.5. Collecting and analysing the data necessary for research requires 23.3 times less time in the prototype environment compared to the same workload in the MS Excel environment;

2. By using the prototype, the authors have been able to determine the profile of GNP Travellers' Days visitors, which is characterized by a sample of the survey. The methodology used to determine the visitor profile is consistent with the current technical capabilities of the prototype to perform automated simple calculations;

3. The technical development of the prototype should be continued, so that the statistical verification of the obtained research results can also be performed.

\section{Acknowledgements}

The article is prepared in the frame of the PostDoc research project 'Integrated Design of Techno-Social Systems: Next Generation of Tourism Monitoring in Latvia' (10.08.2017. Decision No. 9.-14.1/5018 of The State Education Development Agency of Latvia; Project No. 1.1.1.2/VIAA/1/16/110) and supported by the European Regional Development Fund (ERDF).

The authors of the article are grateful to the Nature Conservation Agency of Latvia (LNCA) and the Institute of Social, Economic and Humanities Research of Vidzeme University of Applied Sciences (ViA HESPI) for the permission to use the primary data obtained during the study on national parks' target groups (visitor behaviour).

\section{References}

Association 'Cesis District Rural Partnership (CDRP)' (2019). Nacionālo parku mērkgrupu (apmeklētāju uzvedības) izpēte. (Study on National Parks’ Target Groups (Visitor Behaviour)). Retrieved January 23, 2020, from http://www.ziemelkurzeme.lv/userfiles/files/328/CRLP_PeTiJUMA_ZInOJUMS_Final.pdf. (in Latvian).

Berzina, I. (2012). Assessment of Tourism Economic Significance in the Regions of National Parks of Latvia. Unpublished doctoral dissertation (Full text), Latvia University of Agriculture, Jelgava, Latvia.

Berzina, I., \& Grizane, T. (2011). Kemeru Nacionālā parka apmeklētāja profils. (Visitor Profile of Kemeri National Park). RPIVA VI Conference of New Scientists, 5 May 2010 (pp. 186-192). Riga, Latvia, RPIVA: ISBN 978-9934-8215-7-8. (in Latvian).

Berzina, I., \& Lauberte, I. (2018). The Model of Automation and Extension of Tourism Economic Impact Assessment in Specific Regions. In Annual 24 ${ }^{\text {th }}$ ISC Research for Rural Development 2018 Vol. 2, 16-18 May 2018, (pp. 195-202). Jelgava, Latvia: Latvia University of Life Sciences and Technologies. DOI: $0.22616 / \mathrm{rrd} .24 .2018 .072$.

Berzina, I., \& Lauberte, I. (2019). Tactical Model for Constructing a Prototype of Automatized Assessment of Tourism Economic Impact. In Annual 25 $5^{\text {th }}$ ISC Research for Rural Development 2019 Vol. 2, 15-17 May 2019, (pp. 232-239). Jelgava, Latvia: Latvia University of Life Sciences and Technologies. DOI: 10.22616/rrd.25.2019.074.

BWMC Ltd (n.d.). How Much Data Is There In The World? Retrieved January 20, 2020, from https://www. bernardmarr.com/default.asp?contentID $=1846$.

Diederich, T. (2018, January 5). 5 Limitations of MySQL with Big Data, Friday. GridGain. Retrieved March 2, 2020, from https://www.gridgain.com/resources/blog/5-limitations-mysql-big-data.

EP \& EC (2016, April 27). Regulation (EU) 2016/679 of the European Parliament and of the Council of 27 April 2016 on the protection of natural persons with regard to the processing of personal data and on the free movement of such data, and repealing Directive 95/46/EC (General Data Protection Regulation). Eur-Lex. Retrieved February 02, 2020, from https:/eur-lex.europa.eu/eli/reg/2016/679/oj.

Gero, A., Tsybulsky, D., \& Levin, I. (2019). Research and design triads in the digital epoch: implications for science and technology education [Journal Article]. Global Journal of Engineering Education. 21(1), 80-83. Retrieved January 26, 2020, from https://www.researchgate.net/publication/331841044_Research and_design_triads_in_the_digital_epoch_Implications_for_science_and_technology_education.

International Telecommunication Union (ITU) (2017). Call Detail Record (CDR) Analysis: Republic of Liberia. Final Report. Republic of Liberia: ITU Telecommunication Development Sector. ISBN (electronic version): 978-92-61-20291-0. Retrieved February 20, 2020, from https://www.itu.int/en/ITU-D/EmergencyTelecommunications/Documents/2017/Reports/LB/D012A0000C93301PDFE.pdf.

Jurkāns, I. (2019, March, 3). Mobilo ierīču dati: cik noderīga ir šāda informācija tiem, kas plāno Latvijas attīstību? (Mobile Data: How useful such information is for those planning Latvia's development?). SIA All Media Latvia. Retrieved February 25, 2020, from https://skaties.lv/zinas/latvija/mobilo-iericu-dati-ciknoderiga-ir-sada-informacija-tiem-kas-plano-latvijas-attistibu/. (in Latvian).

LR Saeima (the Parliament) (1993, March 2). Likums Par īpaši aizsargājamām dabas teritorijām (ar Grozījumiem, kas izdarīi līdz 11.01.2014.) (Law On Specially Protected Nature Territories (1993, with amendments 
made until 11.01.2014.)). Latvijas Vēstnesis. Retrieved February 01, 2020, from https://likumi.lv/ta/en/en/ id/59994-on-specially-protected-nature-territories. (in Latvian).

LR Saeima (the Parliament) (2004, October, 8). Elektronisko sakaru likums (ar Grozijjumiem, kas izdarīi līdz 16.01.2020.) (Electronic Communications Law (2004, with amendments made until 16.01.2020.)). Latvijas Vēstnesis. Retrieved January 30, 2020, from https://ikumi.lv/ta/id/96611-elektronisko-sakarulikums. (in Latvian).

Natter, E. (2019, February 25). The Advantages \& Disadvantages of Spreadsheets. Houston Chronicle, Hearst Newspapers, LLC. Retrieved March 5, 2020, from https://smallbusiness.chron.com/advantagesdisadvantages-spreadsheets-26551.html.

PRTA RT (2010, June). Slìteres Celototaju dienas vēstnesis. (Slītere Travellers' Day Bulletin). Retrieved January 15,2020 , from https://www.celotajs.lv/cont/conf/conference/100612-CD/avize/avize_slitere_2.pdf. (in Latvian).

Reinsel, D., Gantz, J., \& Rydning, J. (2018, November). Data Age 2025. The Digitization of the World From Edge to Core. Retrieved January 20, 2020, from https://www.seagate.com/files/www-content/our-story/ trends/files/idc-seagate-dataage-whitepaper.pdf.

TechTarget Ltd (2020). Mobile data. Retrieved March 5, 2020, from https://whatis.techtarget.com/definition/ mobile-data.

Tefficient AB, Ltd (2019, September, 5). Mobile data consumption to grow - a majority of operators now rewarded with average revenue per user (ARPU). Retrieved February 25, 2020, from https://tefficient. com/wp-content/uploads/2019/09/tefficient-industry-analysis-3-2019-mobile-data-usage-and-revenue1H-2019-per-operator-5-Sep.pdf.

University of Minnesota Extension (2020). Visitor profiles. Retrieved February 27, 2020, from https://extension. umn.edu/research-communities/visitor-profiles\#what-information-is-collected\%3F--1522361. 